\title{
THE NEW CODE OF INTERNATIONAL FAMILY LAW.
}

It is now over ten years since the principal powers of Continental Europe began trying to agree upon common rules as to certain subjects of private international law.

Conference after conference was held; always at the same place -the Hague; always at the invitation of the same nation-the Netherlands; largely composed of the same official delegates. A first step was accomplished in 1899 , when a convention agreed to in 1894 by the representatives of fourteen powers and formally ratified by all of them, went into full effect. This established certain rules of judicial procedure respecting suits by foreigners, or evidence procured in one country for use in another. A second and more important stage was reached in 1902, when three new conventions were ratified, which are designed to prevent any conflict of laws as to constitution of the family and the protection of minors, as far as may be, in all the countries between which they were concluded. As to these the ratifications of twelve powers, the Netherlands, Germany, Austro-Hungary, Belgium, Denmark, Spain, France, Italy, Luxembourg, Portugal, Roumania and Switzerland, were formally filed by their diplomatic representatives at the Hague on or before June I2, I902, and the conventions, by their terms, went into effect on August 12, 1902. That as to the guardianship of minors was also ratified by Russia at the same time, and it was intimated by Sweden and Norway that their accession to all three might be expected in the near future.

The main provisions of the convention as to marriage are these:

I. The right of contracting it is governed by the law of the nation of which the parties are subjects, unless that law refers the matter expressly to some other law.

2. The law of the place where the marriage is celebrated may forbid marriages of foreigners related or allied within certain degrees, or the marriage of one divorced for his adultery, or of those convicted of having combined in an attempt to murder the husband or wife of either of them; but no marriage thus forbidden 
shall be void if allowed by the law of the nation of which both parties are subjects.

3. The marriage of one under a religious vow of celibacy in a country where it is not prohibited, though it be prohibited by the country of which the parties are subjects, may be valid in the former; but other countries have the right to treat it as invalid.

4. Foreigners seeking marriage must first prove that it is permitted to them by the laws of their own country.

5. As to the form of marriage, the law of the place of celebration controls; provided that countries requiring a religious ceremony are not bound to recognize a purely civil marriage of their subjects while abroad.

A previous publication of the intention of the parties to marry, if required by the law of their own nation, should be made; but the want of it will not nullify the marriage in other countries.

6. Marriages between foreigners before a diplomatic or consular officer of their own nation will be good, if the law of the place does not forbid it for other reasons than those founded on a prior marriage or religious vows.

7. A marriage, void as to form where it is celebrated, may be recognized in other countries, if the form under the national law of the parties has been followed.

8. This convention applies only to marriages celebrated in and one party at least to which comes from one of the contracting powers; and no national law need be respected except that of one of those powers.

9. It applies only to the European possessions of the contracting powers.

It will be perceived that the system thus elaborated is one of compromises. Those affecting the church and religious orders were insufficient to satisfy Russia, whose delegates signed the protocol of this convention with an express reservation as to these points, and made their views known on the floor of the Conference.

The nationality of the parties is treated, in this and the other conventions alike, as a more decisive test of the law that ought to be applied, than that furnished by the law of their domicil. That logically follows from the Roman conception of the family as the political unit of society rather than the individual. This has been inherited by Europe. Italy, as the immediate child of Rome, has, since her new birth as a nation, taken the lead in pressing the theory of nationality as decisive of status, and her delegates at the Hague Conferences lost no opportunity of asserting this doctrine. 
American jurists have been more inclined to rely on domicil, as a safer test. Our political circumstances have led us in this direction. Many an immigrant spends his life in this country without ever formally changing his native allegiance. All must spend five years here. before they can accomplish it. Meanwhile they are contracting new relations and acquiring new possessions. Most of them belonged to the poorer and more ignorant classes in their own country, and knew little of its laws, except that they found then oppressive. If they marry here, the ceremony and conditions would naturally be such as may be dictated by the laws of the State in which it is performed. If they die, the care of their children can be most readily provided for under the laws of the State where they belong.

On the other hand, what emigration there may be from one European State to another is largely of those who are intelligent, enterprising and well-to-do. It never assumes the proportion of a national movement. Those who thus leave their country generally hope to return. The very idea of a voluntary change of allegiance, as within the power oi a subject, is new to Europe. Each State there also has a distinctive character and jurisprudence, which has no parallel in the United States, with their central governments so colorless as regarcis most family relations, and local governments pursuing in the main the same lines of legislation in respect to them. and inheriting similar social usages and institutions.

The convention as to divorces, including both those $a$ vinculo matrimonii and those a mensa et thoro (séparations de corps), contains these provisions:

I. An action for divorce can be brought only when authorized both by the national law of the parties and by that of the place.

2. The cause of divorce must be such as is allowed under the laws of each of these countries.

3. Nevertheless, if the law of the place permits it, the national law will control.

4. This national law will not avail to make anything occurring when one of the parties was of another nation a cause of divorce, when it was not such a cause when and where it occurred.

5. Divorce suits may be brought before a court having jurisdiction according to the national law of both parties, or according to the law of their present domicil. When jurisdiction rests on 
domicil and they have different domicils, suit must be brought in that of the defendant. In case of an abandonment or of a change of domicil after the date of the cause of divorce, suit may also be brought in the courts of the last common domicil.

Nevertheless, resort must be had to the courts of their own nation, if these are alone competent to decree the divorce. In case of a marriage such that the national courts of the parties could not dissolve it, divorce may be sought elsewhere.

6. Where divorce is not allowed in the courts of the country where the parties are domiciled, they may apply to them for temporary relief from living together, which may be extended as long as the laws of that country permit, if confirmed within a year by the courts of their own nation.

7. Divorces granted agreeably to this convention will be valid everywhere, provided the defendant, if he did not appear, was regularly notified in the way demanded by his own national law as necessary for upholding ordinary foreign judgments. This applies to those granted otherwise than by courts (e.g. by a royal decree) only if they are recognized as valid by the national law of each of the parties.

8. If the parties are of a different nationality, the laws of the country by which both were last governed will be considered as their national law.

9. This convention applies only to divorces sought in and one party at least to which comes from one of the contracting powers; and no national law need be respected except that of one of one of those powers.

Io. It applies only to the European possessions of the contracting powers.

The American Bar Association, some years ago, urged upon the States for adoption a statute giving jurisdiction of divorce suits only in case one or hoth of the parties had a domicil within the State. It was enacted by one or two, only; most of them preferring to require nothing more than a residence for a stated period. Such a residence in a place does not neccessarily indicate that it had become the man's home. Hence a wide door is opened for fraud. A citizen of one State may take up his headquarters for six months or a year at a hotel in another, and then, perhaps, on publication in some local newspaper of the fact that he has instituted an action of divorce, or on proof that a copy of the process has been mailed to 
his wife, can, if she does not appear to defend, speedily secure a divorce, which will be valid there, but very possibly valid nowhere else.

This has given rise to many scandals in the administration of American justice.* For us, however, to adopt the plan which has now received the adhesion of most of Europe, would be hardly less objectionable. It would let the foreigner who has lived for years in the United States institute a suit for divorce in the courts of his own country, three or four thousand miles away, against which, on account of expense and distance alone, it would, in most cases, be next to impossible to make defence.

Some provision as to divorces granted otherwise than by decree of court, or as the Conference phrased it pronounced par une jurisdiction administrative, was a practical necessity. Marriage is a status. Until 1858 , in England, it was the doctrine that such an alteration of this relation as a divorce creates could only come from direct legislation. To change a man's legal status was to change the law defining that status. Divorces a vinculo matrimonii were therefore granted only in special cases, and by Act of Parliament. That legislative divorces are valid, in the absence of constitutional prohibitions, has always been the American doctrine. $\dagger$ The provision made in this respect in the convention of 1902 is. in the nature of a restriction of this view. Non-judicial divorces need not be recognized, unless they are good by the national law to which each of the parties is subject. Thus limited, it is a decided step in advance, and safeguards the constitution of the family better than private international law has ever done before.

The convention as to the guardianship of minors has these provisions :

I. The guardianship of a minor is regulated by his national law.

2. If under that law guardians are not appointed for non-resident minors, proper proceedings may be taken by the diplomatic or consular officers of the nation to which such a minor belongs, in the country of his residence.

*See Briggs v. Briggs, Law Reports, 5 Probate and Divorce $16_{3}$ in which a Kansas divorce was held no defence to a charge of bigamy predicated on a subsequent marriage. Cf. Yale Law Journal. XII, 385.

tMaynard v. Hill, I25 U. S. Reports, rgo. 
3. As to a non-resident minor, for whom no guardianship has been constituted agreeably to articles $I$ or 2 , one can be established and conducted according to the laws of the country of his residence.

4. Such a guardianship will give way to one subsequently appointed under articles $I$ or 2 ; and prompt notice of any such appointment shall be given to the government of the country where the minor resides.

5. Every guardianship begins and ends at the times and for the causes fixed by the national law of the minor.

6. A guardianship extends to the person of the minor and all his property, wherever it may be, except immovable property subject to a special local law.

7. In any case of emergency; the person and property of a foreign minor may be protected by local authorities.

8. A power finding a foreign minor within its territory, for whom a guardian ought to be appointed, will give prompt notice to the nation of which he is a subject; which will in turn give prompt notice if a guardian has been or will be appointed.

9. This convention applies only to minors belonging to or habitually residing in one of the contracting powers, and who are in its European possessions.

Here again it is the national law to which the family, through its head, has been subject. which on the removal of the head regulates the succession to his authority, and regulates it everywhere.

A great practical advantage is thus secured in the management of a minor's property. It is confided to a single official, responsible to a single tribunal. A guardian appointed in Moscow can collect a debt owing to the minor in Naples, and account for it only in accordance with the rules of Russian jurisprudence.

American legislation has been of late years moving in the same direction, and it is quite within the bounds of possibility that this distinctive feature of the Hague convention may yet be adopted generally throughout our States.

I have used the terms "official" and "appointed," because these best represent the nature of guardianship to an American. They inclucle, of course, those whom the general law may name, or authorize a family council to select.

These three conventions have been described in the title of this article as a new code of international family law. It is, of course, not a full one. It assumes to touch only a few points. But these 
are each of the first importance. There will henceforth be few questions made in European courts as to whether an alleged marriage was a true marriage, or an alleged divorce an effectual divorce. The fundamental conditions to which the parties were obliged to conform have been settled, and are so plainly stated that the proper rule can be easily applied.

It would, of course, have been idle to attempt to make the law of each of the powers the same, in matters like these. Religion, custom, social prejudices, all stood in the way. It was practicable to say which, in a particular case, of several different laws should govern; and that has been well done. This required considerable concessions on the part of several of the powers. France, especially, waived a good deal that she had long cherished, as to the necessary prerequisites for a marriage of her citizens abroad. Some of the nations represented had, on their own initiative, modified their laws between the first and the latest of the Hague Conferences, upon subjects otherwise likely to present obstacles to any agreement. Hungary was one of these, having made important changes in her marriage laws.*

The avant-projet of each convention was matured by a small commission, headed by some publicist of distinction, and to whom suggestions were freely made by the other members of the Conference. The President of each of the Conferences, Professor. Asser of Amsterdam, did much towards steering both them and the several commissions in a safe course. Austria, for instance, objected strenuously to allowing, under any circumstances, marriages in violation of a religious vow, or between Christians and non-Christians. It was Professor Asser who proposed the compromise adopted. True, he said, Austrian law provides no functionary who can marry a Christian to a Jew. She may forbid such alliances, if she thinks proper, between her own subjects, but she ought not to insist that foreigners of these descriptions should not intermarry upon her soil in the legation or consular offices of their own government. This does not demand her co-operation, nor depend upon her sovereignty. $\dagger$

This brief review of the new code shows that it is not one to all the principles of which the adherence of this country can be expected. It is of a nature aclapted to States not far distant from

* Actes de la Troisième Conférence de la Haye pour le Droit International Privé, I68.

†Actes de la Troisième Conférence de la Haye pour le Droit International Priz'é, 17I 
each other, and deriving their notions of private and personal rights mainly from those of the Roman law. The United States, as a nation, can hardly under any future conditions so far change their traditions as to extend the treaty power to a concert of legislation, on matters of such a character, with nations on other continents. The States, acting individually, could not become parties to such a concert, for it is expressly forbidden by the Constitution of the United States. They can, with the consent of Congress, agree among themselves to establish similar conventions, and they can, without that consent, change, each for itself, their laws so as to bring them into closer accord on these subjects, or any other. They have been doing this for the last dozen years through the annual Conference of Commissioners on Uniform State Legislation, in which most of the States and Territories are now represented. But it is as easy to repeal as to enact. There is, therefore, no assurance of stahility to the beginnings of uniform legislation which have been made at the instance of these Conferences or of the American Bar Association. In this the powers of Europe occupy a position much more favorable to permanence of policy. The three conventions of 1902 must remain in force until I907, and will then be tacitly renewed, unless explicitly denounced.

In the case of several of the powers, the conventions were ratified not only by the administrative authorities but by the legislative, thus gaining an additional assurance of stability.

This, however, is best guaranteed by the intrinsic character of the conventions, themselves. They have not attempted too much. They have not aimed at establishing uniform laws, but uniform rules for applying family law. Its design is simply to prevent a conflict between the laws of one country and those of others on the same subject, by determining in advance, by means of general regulations, which shall govern. Each may think its own laws the best, and yet each may, without any inconsistency, agree to let foreigners, in certain cases, be subject to foreign rules with which they may be expected to be more familiar.

Simeon E. Baldwin. 